\title{
Possibilities of usage meta-analysis method in economic research
}

area

Ph D. Anna Gondek University of Zielona Góra, Faculty of Economics and Management

\section{Introduction}

In the last decades, on account of technical possibilities which were provided by Internet, a scientific neighbourhood was widened very noticeably. Scientists, especially who knows English, have today almost unlimited access for academic achievements of their friends all over the world, provided that their scientific papers were digitize. Even though the process of the digitization in countries of Centre Europe started relatively recently, now it is already possible to say about almost unlimited access to bases of academic publications.

Such a convenient situation induces many researchers for seeking similar to their studies in the world of science, undertaking comparative examinations or also confirming or rejecting achieved results. Taking such activities requires the knowledge of the synthetic literature review methods.

A purpose of the article is a presentation of meta-analysis as the method of the synthetic data analysis and showing wide possibilities of applying it in the economic research, in which it is very rarely applied in Poland even though researchers from the entire world apply it universally. Not only a lack 
of the knowledge of English, but also a lack of the awareness of the existence of meta-analysis can be a cause of such a state of affairs. It is confirmed by absence of meta-analysis in the economic literature about methodology of research.

In order to indicate areas of research in economic studies by researchers from all over the world the author reviewed scientific papers placed in international bases in the last ten years.

\section{Enter meta-analysis}

Sometimes, the great faith into isolated examinations may lead to incorrect results. It happens when the examination was conducted defectively or it is unimportant statistically. Moreover, in the many parts of the world the similar or the same phenomena and processes were researched and this fact also was a source of inspiration for seeking methods linking findings. In seventies first efforts of creating such a method were already comprehended.

In 1976 Glass introduced the term meta-analysis as an analysis of analyses (Glass, 1976, pp. 351-379), but till now a single well-accepted definition or a single methodology of this method has not existed (Shelby, Vaske 2008). Generally speaking meta-analysis is a statistical procedure of synthesize the quantitative results of many empirical studies (Glass 1976, pp. 351-379, Hedges 1987, pp. 443-455, Rosenthal 1978, s. 185-193). Differences in definition result from controversy around such problems as (Shelby, Vaske 2008, pp. 96-110): (1) is meta - analysis a total methodology or an analytic technique, (2) usage of effect sizes, (3) what is the unit of analysis, (4) finding differences between meta-analysis and comparative analysis. In the paper, the Glass's definition was accepted and according to him meta - analysis is "the statistical analysis of a large collection of analysis results from individual studies for the purpose of integrating the findings (1976).

In the eighties of the last century, meta-analysis was recommended to solve medical problems and social and behavioral research (Field 2001, pp. 161-180). Nowadays all over the world this method is used in many areas - for medical problems, technical, social and economical many other ones. In economic and management area first meta-analyses have just appeared in Poland (Gondek, Mazur 2010, pp. 143-157, Mazur 2011a, pp. 105-118, Mazur 2011b, Mazur 2012, pp. 40-53), but still it is not applied widely.

First of all, meta-analysis should be place among quantitative methods but in fact it is one of literature review methods (figure 1). There are four main 
methods; they are: narrative review, descriptive review, vote - counting and meta-analysis.

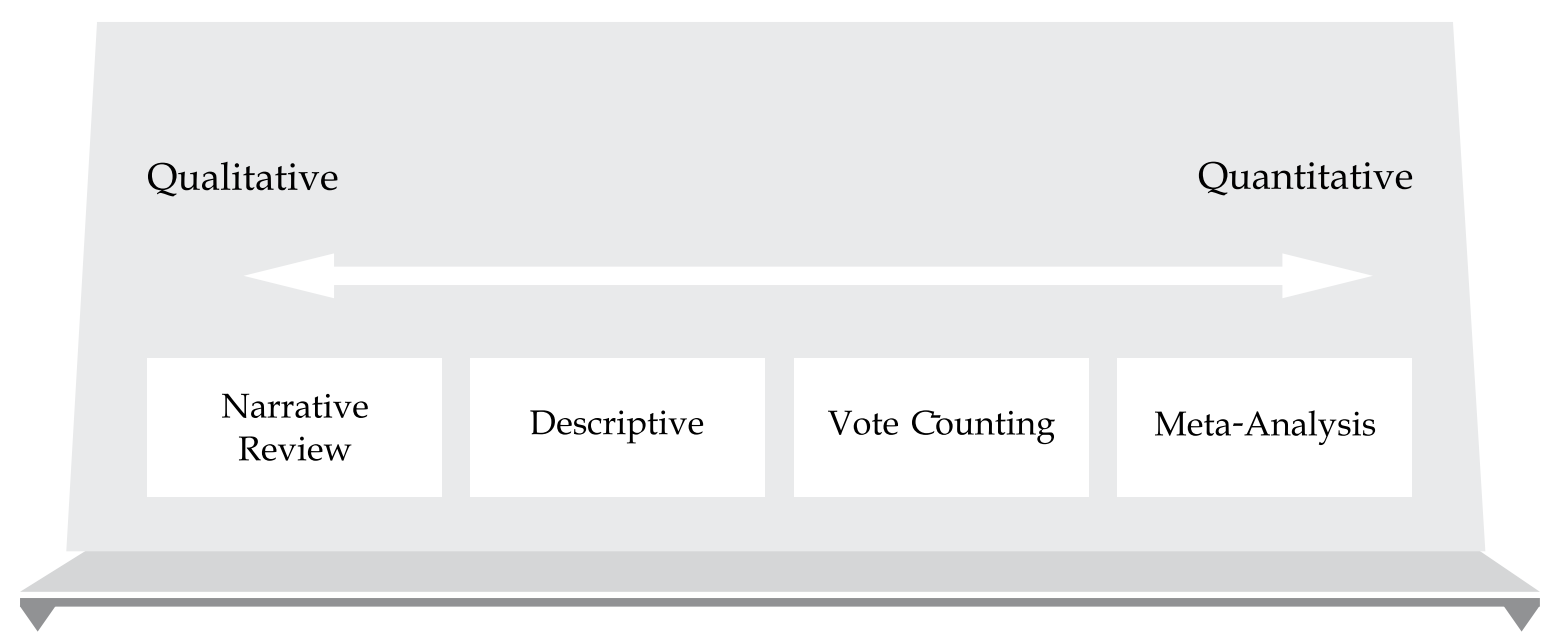

Figure 1. Review Methods on a Qualitative-Quantitative Continuum

Source: King, He 2005 after Guzzo et al. 1987, pp. 665-686

On the one side is narrative review. It is the most qualitative method in comparison to others. On the second side, there is meta-analysis, which is the most quantitative method in all these literature review method. This paper is about meta-analysis, that is why the other methods of literature review are not described here.

\section{Meta - analysis procedure}

As it was mentioned,meta-analysis is the most quantitative method among others. It has got strict statistic procedure and is conducted in four steps (Mazur 2001b):

1. Conceptualization and operationalization of research problem on the basis preparatory analysis of accessible outcomes. The first step is to conceptualize the research problem. Literature review is necessary here, for example with narrative review or descriptive review. Not only a variable (variables) is being set, but also whether the researcher is interested in strength of relation of the chosen variable (variables) with other variables or perhaps with its (theirs) changeability. Usually effect size comes from the so-called 
$r$ family (when a correlational of the variable with different variables is examined) or from the so-called d family (when a changeability of results is the subject to an examination).

2. Data collection with the criteria of study including. It is good to collect as many studies as possible. Even not significant studies. In economics area it is good to use international scientific base for example EBSCO, PROQUEST, ELSEVIER, Emerald or Wiley Online Library. Normally, researchers give information which bases they used, what was the question to the base and how many answers they received. When this set is complete, the criterion of including should be fixed. It is important, if research phenomenon is understood and counted in the same way through individual studies. In is for avoiding linking bad studies. Than the studies are coded. Coding must be in order to reducing individual attitude of researcher to studies.

3. Selection, putting together and comparing findings. Criterions of including reduces of number of studies. Results must be put together and put into groups (if is necessary) Typically data is from so-called d-family (based on standard deviation) or r-family (based on correlation).

4. A statistical analysis and formulating results.

A statistical analysis is based on a few steps, and they are (Mazur 2001b, Shelby, Vaske 2008):

- count effect sizes for each study independently,

- count weighted mean of effect sizes,

- determine the confidence interval for the mean,

- analyze homogeneity.

Analysis oh homogeneity is very important. In practice there are two possibilities - distribution of effect sizes can be homogenous or heterogeneous. If the distribution is homogenious, the values are concentrated around the mean and it gives a base for results. But if the distribution is heterogeneous, then Fixed Effect Model or Mixed Effect Model or Random Effect Model should be applied, which are described in the body of the literature (e.g., Raudenbusch 1994, pp. 301-321, Shadish, Haddock 1994, pp. 261-282, Lipsey, Wilson 2001, p. 218, Hedges 1982, pp. 353-398, 1994, Hedges and Olkin 1985, p.314, Cooper, Hedges 1994, p. 215). After statistical analysis the researcher can formulate results. It is good to use figure, where $\mathrm{x}$ axis describes number of samplings and $\mathrm{y}$ axis describes the effect sizes. 


\title{
4. The advantages and disadvantages of meta-analysis
}

\author{
Every method has its own limitations. Typical advantages and disadvantages \\ of meta-analysis were put together into table 1.
}

\section{Table 1. The advantages and disadvantages of meta-analysis}

\begin{tabular}{l} 
Advantages of meta-analysis \\
\hline - it is less appraising than different than \\
different literature review mathods, \\
- it takes into account results form \\
a individual study and size of sampling, \\
as well,
\end{tabular}

- it uses result with no information who is the author of the study or the place of publishing,

- it has got its own strict statistical procedure,

- because of synthesis of result, the total size of sampling increases,

- studies without significant result can be included into meta - analysis,

- it can settle doubts between contradictory studies or also to deliver conclusions from examinations which did not bring explicit conclusion,

- it performs both function confirming relations in nature and explanations in relation to examined phenomena and processes,

- it can be an inception step for a research showing the wide spectrum of achievements and research trends; this advantage is especially useful if current results are ambiguous,

- it can indicate the statistical significance in the future. For that purpose studies should be gathered from a historical perspective,

- it unable to find differences and resemblances in outcomes methodology of leading studies.
Disadvantages of meta-analysis

- many studies cannot be synthesized for example concerning the structure, conceptual models, studies of cases, examinations about speculative character and comment papers, statistical and mathematical models, interviews or quality studies,

- if the researches uses the triangulation only a quantitative part can be included in metaanalysis with omitting quality part which can more contribute to conclusions drawn in the study,

- increasing the sample size does not always mean that credibility and representative of achieved results increase,

- it does not diversify studies on account of their quality,

- it do not solve the outlier problem,

- some econometric problems as unobserved heterogeneity, unexplainable or partially explainable heterogeneity, heteroskedasticity, non-independence of estimates from primary studies can appear during conducting of metaanalysis,

- studies with significant results are published more often than studies with "weaker" results and that is why they are more possible to be included into meta-analyses,

- conducting this method it is possible that „apples and oranges" are included into the research and compared to each other,

- 15 is the required minimum number of studies

- the publication of results of meta-analysis requires giving to the author of quite big editorial possibilities, because meta - analysis usually increases the length of the text.

Source: own elaboration on the basis Bal et. al, 2002, Field 2001, Glass 1976, Mazur 2001b, King, He 2005, Nelson, Kennedy 2009, Rosenthal 1991, Shelby, Vaske 2008 


\section{Meta - analysis in the economics research area}

Meta-analysis can be applied in many economics research areas. The author of the article made a research which aim was to find any meta-analysis from the economics area published in scientific journals which are present in international scientific bases as: EBSCO, PROQUEST, ELSEVIER and Wiley Online Library. The author ask for "meta - analysis" in the title of article and "economy" in the text and received 219 answers. Than the indicated papers were investigated if they really were about asked question and included full meta - analysis research about economy (the author exclude the medical and psychological papers). Then, the set of article reduced to 190 articles. Next papers about methodology of conducting meta- analysis were excluded form the set and in the end the set of 188 were taken into account. Some articles are published in two or more bases, and that is why the set reduced to 172 papers. Than the articles were divided into twelve subject groups.

Assigning to focus groups in case of many publications created the problem on account of their interdisciplinary character, then they were guided by keywords shown by the author/the authors. Moreover, a detailed division of disciplines and economical specializations existing in English-language literature does not always cover with Polish names. Additionally, a lot examinations are based by rates concerning different fields. In spite of these problems, after all the following groups were created:

- development and growth economics, sustainable development, national accounts, public budgeting and finance,

- management,

- population and social conditions, education, human capital,

- environmental economics,

- labour economics,

- transport economics,

- regional economics, regional studies, urban studies, rural studies,

- agriculture and fishieries,

- tourism and recreation,

- energy affairs,

- science and technology,

- political economics.

Border among above groups they are not sharp, nonetheless a need of creating them existed because of research considerations. Names of these groups were created in this way that they showed the main subject of examinations which 
had an economic character. For example the group named "Energy" means a set of the economic research tied together with the energy subject i.e. in the metaanalysis the variables describing occurrences from energetics were connected with economic variables.

The most numerous group was a set of articles devoted to the development and the growth of the economy as well as sustainable development, national accounts and public finance (31 studies). These occurrences have most often been connected with the productivity, the corruption, the unemployment and the employment, taxes, the democracy, the innovation, the tourism, the financial sector, the foreign direct investment, the export, the social capital, the industry, the financial crisis and expenses on military aims.

The second group was the set of studies about managements ( 29 studies). The most studies concerned issues from the area of the productivity, the quality of the human capital, attitudes towards the organization, as well as the widely understood competitiveness.

Other sets contained articles from the area of the labour market in connecting with other variables like e.g. the service quality, human resources, working hours or the minimum wage, as well as from the area of the economics of the transport, regional economics e.g. in connecting with the climate change, the farm tourism, the tourism, the energy market, the science and technology, and the political economics. The number of publications coming from these areas of research fluctuated from a few for a dozen or so studies. However on account of the bluntness border among these sets and interdisciplinary nature of numerous studies, analysis of the number of these sets seems groundless.

The most of meta - analysis included into researched papers regarded about correlation between chosen variables, what means that authors of the research were interested in relationship between phenomena. Many studies was econometric characters. Moreover, meta-models and meta-regression were presented in studies, because during last twenty years meta-models and metaregression were developed in econometric area.

A fact which is worth of notice is that researchers who make meta-analysis frequently determine the geographical framework dividing economies to developed and developing economies, to Western Europe and the United States and to Centre and Eastern Europe, however examinations for the area of China in general appear separately. Perhaps it results from the fact of the dynamically developing Chinese economy, and consequently indicators describing it could indeed affect the result of analysis or to enter the problem of outliers into metaanalysis, which so far has been solved yet in the procedure of meta-analysis. 


\section{Resume}

The presented method of the literature review - meta-analysis finds the wide application in international researches from the area of economic studies. Experienced researchers uses it both to solving macroeconomic problems, as well as microeconomic ones. In spite of numerous restrictions of this method, it should be stated, that its advantages must exceed disadvantages, since it has such a great popularity with researchers publishing in English.

\section{Summary}

\section{Possibilities of usage meta-analysis method in economic research area}

The article presents the method of meta-analysis showing its essence, main elements, steps of carrying out research, as well as showing the advantages and disadvantages. In the support to available scientific bases of the source body of the literature, the author checked the economic studies, in which meta-analysis was used and divided them into twelve subject groups. Two group were the most numerous, they were: (1) macro-economics in such subjest as development and growth economics, sustainable development, national accounts, public budgeting and finance and (2) management, especially about productivity, quality of human capital, organizational attitude, and widely understood competitiveness.

Keywords: metaanaliza, effect size, methodology.

\section{Streszczenie}

\section{Możliwości stosowania meta analizy w badaniach ekonomicz- nych}

Artykuł prezentuje metodę metaanalizy pokazując jej istotę, główne elementy, etapy prowadzenia badania, a także ukazując wady i zalety. $\mathrm{W}$ oparciu do dostępne $\mathrm{w}$ bazach naukowych źródła literaturowe dokonano przeglądu badań ekonomicznych, w których wykorzystano metaanalizę. Badania te przyporządkowano do dwunastu grup tematycznych. Dwie drupy były najbardziej liczne, były nimi: (1) badania makorekonomiczne w takich obszarach jak wzrost i rozwój ekonomiczny zagadnień 
z obszaru efektywności pracy, jakości kapitału ludzkiego, postaw wobec organizacji, a także szeroko rozumianej konkurencyjności.

Słowa

kluczowe: metaanaliza, wielkość efektu, metodyka.

\section{References}

1. Bal F., Button K.J., Nijkamp P. (2002), Ceteris Paribus, Meta-analysis and Value Transfer, "Socio-Economic Planning Science”, 36 (2).

2. Cooper, H.M., Hedges L.V. (Eds.) (1994), The Handbook of Research Synthesis, Russell Sage Foundation, Nowy Jork.

3. Field, A.P. (2001), Meta-Analysis of Correlation Coefficients: A Monte Carlo Comparison of Fixed-and Random-Effects Methods, "Psychological Methods", no. 2.

4. Glass, G.V. (1976), Primary, Secondary, and Meta-Analysis of Research, "Review of Research in Education”, no. 10.

5. Gondek A., Mazur K. (2010), Job satisfaction, organizational commitment and job performance - partial meta-analysis, "Management", no 1.

6. Hedges L. V. (1982), Issues in meta-analysis, Review of Research in Education, no. 13.

7. Hedges L.V. (1987), How hard is hard science, how soft is soft science?, "American Psychology",no. 43.

8. Hedges L. V. (1994), Statistical considerations. In H. Cooper and L. V. Hedges (Eds.), The handbook of research synthesis, New York: Sage.

9. Hedges L.V., Olkin I. (1985), Statistical Methods for Meta-Analysis, Nowy York.

10. King, W.R., He J. (2005)Understanding the Role and Methods of Meta-Analysis in IS Research, "Communications of the Association for Information Systems", no. 3.

11. Lipsey M. W., Wilson D. B. (2001), Practical meta - analysis, Thousand Oaks, CA: Sage.

12. Mazur K. (2012), Leader-member exchange and individual performance. The meta-analysis, „Management” 2012, no. 2.

13. Mazur K. (2011a), The impact of organizational justice on employee behaviour related to value creation. A meta-analysis, "Management” 2011, no 2.

14. Mazur K. (2011b), Tworzenie i przywłaszczanie wartości: perspektywa relacji: pracownik - organizacja, Oficyna Wydawnicza Uniwersytetu Zielonogórskiego, Zielona Góra.

15. Nelson, J. P., Kennedy P. E. (2009), The Use (and Abuse) of Meta-Analysis in Environmental and Natural Resource Economics: An Assessment, „Environmental and Resource Economics", 42 (3). 
16. Raudenbusch S. W. (1994), Random effect models. In H. Cooper and L. V. Hedges (Eds.), The handbook of research synthesis, New York: Sage.

17. Rosenthal R. (1978), Combining Results of Independent Studies, „Psychological Bulletin", no. 1.

18. Rosenthal R. (1991), Meta - analytic Procedures for Social Research, revised edition, Beverly Hills, CA: Sage.

19. Shadish W. R., Haddock C. K.(1994), Combining estimates of effect size. In H. Cooper and L. V. Hedges (Eds.), The handbook of research synthesis, New York: Sage.

20. Shelby Lori B., Vaske Jerry J. (2008), Understanding Meta-Analysis: A Review of the Methodological Literature, "Leisure Sciences”, no. 30. 